Article

\title{
Framing Climate Services: Logics, Actors, and Implications for Policies and Projects
}

\author{
Marine Lugen $(\mathbb{D}$ \\ Centre d'Etudes du Développement Durable, Université libre de Bruxelles, ULB C130/03 Avenue F.D. Roosevelt 50, \\ 1050 Brussels, Belgium; marine.lugen@ulb.be
}

Received: 12 August 2020; Accepted: 28 September 2020; Published: 30 September 2020

check for updates

\begin{abstract}
This paper explores how climate services are framed in the literature and possible implications for climate services' policies and projects. By critically exploring the frames around climate services, the wider objective is to encourage more reflexive and responsible research in the field, particularly given the huge challenge that climate change represents. By using a framing analysis based on an extensive literature review, five dominant frames were identified. Climate services are mainly framed (1) as a technological innovation, (2) as a market, (3) as an interface between users and producers, (4) as a risk management tool, and (5) from an ethical angle. The predominant frames influence how we think about climate services, shared assumptions, and the way in which policies and projects are designed. To prevent negative effects of climate services on the ground, such as inequalities, the main recommendations include establishing interdisciplinary and transdisciplinary dialogues between different communities of practice and players, increasing empirical and social science research to improve our understanding of this new field, and finally, re-thinking climate services in terms of adaptation rather than as the mere production of new information products.
\end{abstract}

Keywords: climate services; climate information services; climate change adaptation; framing analysis; discourse analysis; climate policy

\section{Introduction}

At the World Climate Conference-3 held in 2009 in Geneva, the heads of states, governments, ministers, and heads of delegations decided through the conference declaration to establish a Global Framework for Climate Services (GFCS) to be coordinated by the World Meteorological Organization (WMO) [1]. Climate services, or climate information services (CIS), can be simply understood as the production and delivery of climate information to assist decision-making [2]. While they are based on the same core of data production and service delivery systems as weather services [3], they are distinct, as climate services produce information about average weather to estimate, for instance, trends and scenarios [4]. Climate services are expected to include "data, information and knowledge that support adaptation, mitigation and disaster risk management" [5] in the context of climate change. Poor understanding and access to climate information is regularly highlighted as a barrier to adaptation [6-8]. Hence, producing high-quality, understandable and usable climate information is increasingly recognized as fundamental to the resilience of societies $[1,4,9]$. CIS are shaped as part of a corpus of solutions to face climate change, particularly, a way to inform decision-making and encourage adaptation strategies. They are expected to support national and local adaptation planning, inform risk-reduction strategies and assist decision-making in a range of climate-sensitive sectors [10-12].

Since the establishment of the GFCS, a new climate services community has emerged [13-15]. Climate services have been actively promoted by several international organizations, such as the WMO and European Union. Consequently, they have been established at local, national, and regional scales [14, 
16,17] all over the world in recent years [18]. They attract numerous actors such as development agencies, researchers, administrative authorities, the private sector, and non-governmental organizations (NGOs). Funding for climate services is expected to increase considerably in the near future [19].

In this context of growing attention, it is important to understand the current development of CIS as a field, ten years after the creation of the GFCS. The literature on CIS to date has focused heavily on the types of products to develop [20-22], the needs of users for climate information [23-25], the barriers to adoption [26,27], and the models of knowledge production and communication [28-32]. However, little attention has been paid to how and why various conceptualizations around climate services have been developed by different actors. As Harjanne stated [33] (p. 3), "why climate services are necessary and needed is discussed much more than what climate services are". It is important to understand the way in which CIS are shaped and according to which logics and based on which types of knowledge they are shaped, as this reflects on how we design and implement climate services on the ground. The frames around climate services have implications for how they are discussed and, consequently, some cross-cutting issues that weigh on policy and practice. Discourses relate not only to an abstract process that creates meaning but also to concrete practices that flow from this process. When tackling political problems, a discourse can give rise to a specific interpretation of its nature (the "diagnosis") and thus determine the suite of possible solutions to pursue in the context (the "prognosis") [34]. A discourse can strongly influence political decisions and socioeconomic institutions. This is what Hajer et al. [35] call the "institutionalization of the discourse".

To date, only one paper has approached discourses around climate services [33], and very few papers offer critical analysis [36-38]. This paper aims to partially address this gap by critically exploring the frames around CIS and the possible implications for climate services policies and projects. Given the huge challenge that climate change represents, a wider objective is to encourage more reflexive and responsible research into CIS.

\section{Framing Analysis}

The concept of framing comes from the work of Erving Goffman, an influential North American sociologist, psychologist, and writer. The act of framing can be described as a process by which actors construct and represent meaning to understand an event, process, or occurrence [39,40]. According to Goffman [40], frames enable individuals "to locate, perceive, identify, and label" occurrences or information. Framing occurs when people with different knowledge, experiences, and personal backgrounds consider a common issue and attempt to make sense of it from their individual or organizational perspectives. The resulting frames help the actors to identify the processes they are engaged in and contextualize them within a set of values, ideas, and/or political agendas [40]. The framing process therefore contributes to producing a shared meaning and sense of purpose for complex socio-ecological phenomena, such as climate change.

Framing analysis is a type of discourse analysis that aims to identify framing processes. Framing analyses can help to elucidate the underlying logics, contestations, and values of actors (not necessarily in strategic or conscious ways), with consequences for the scope of policy action [41]. Indeed, framing can be decisive in knowledge production, and it influences research agendas, policy development, and implementation [42,43]. The framing approach additionally draws attention to ways in which actors rely, both intentionally and unconsciously, on intrinsic resources to define the boundary of an issue [41]. A frame can favor some options, while ruling out others.

Framing research draws on literature from cognitive, constructionist, and critical studies [44]. Since the early 2000s, the concept of framing has been increasingly used in several academic fields such as sociology, economics, psychology, cognitive linguistics, communication, political science, and media studies $[45,46]$. The concept of framing is particularly used in the analysis of public problems and the construction of collective action [47]. Several approaches exist in framing analysis. Studies distinguish framing by virtue of their sociological foundations—communication frames and content-on the one hand, and of their psychological foundations—-the effects that frames have on their receptors—on the 
other hand [48]. This article settles on the first: the focus is on the existence of frames, the actors who support them, the content they transport, and the way they influence how CIS are conceptualized, built, and implemented.

Framing analyses have been used by scholars of environmental change [41,49], including climate change [43,50-53]. Such studies have shown that different frames can be formed depending on the perception of climate change and its reality, depending also on the climate risks highlighted, the role associated with adaptation, the objectives defined as priorities, the actors designated to consider such objectives, and the means identified to facilitate adaptation $[42,54]$.

Working specifically on climate change adaptation, McEvoy et al. [43] identify frames at three different levels: meta, conceptual, and operational (see also [36,44]). First, at the meta-level, public discourses often frame climate change issues by actively drawing on values and beliefs [55]. Media frames, especially, rely heavily on values and questions of power to influence research, policy development, and decision-making. Second, framing occurs at the conceptual level, as manifested in theorizations of adaptation processes and outcomes, and in the definition of abstract scientific concepts. A good example is the role that scientific disciplines play in the framing process: individual disciplines and their associated academic networks can be understood as communities of practice [56], which "make meaning" [57] by creating and reinforcing a shared frame around their research topic [43]. Consequently, frames are revealed in common key hypothesis, methodologies, values, or widely shared assumptions in the form of a specific expert language [58]. The third level of framing is operational, where practical adaptation decisions are made, and actions are taken. Frames are then reflected in strategies, policies, and choices of processes for adaptation [43].

This paper mainly explores the conceptual level of framing for climate services. Therefore, the emphasis is on the theorization process regarding climate services, as the procedures for defining abstract scientific concepts. Climate services are a concept predominantly considered by experts rather than in everyday life. Therefore, the conceptual level is currently the most important for climate services. As they relate to many societal challenges and divergent scientific domains (e.g., hazards, urban planning, risk management, adaptation, etc.), different communities are beginning to converge within a new climate services community. This opens the door to potential overlap and competition between communities of practice [43]. Competing frames might cancel each other and reinforce existing values, push individuals in conflicting directions, or increase motivation for a more careful evaluation of the alternatives [59]. They have a fundamental influence on the way in which practices and policies are consequently designed. What ultimately matters is not how frames meet or do not meet scientific requirements, but rather which interpretations are facilitated by them and to which ideologies such interpretations belong, as well as to what extent one frame (compared to another) ultimately strengthens forms of knowledge, resources, and power over the interpretation of events [60]. Therefore, as a secondary objective, this paper partially explores the operational level of framing by looking at how conceptual frames can influence CIS policy and practice. Overall, the points for attention are implicit and include actors (including individual backgrounds) invested in the field of climate services and factors that influence their definition. Looking at authorship and institutional structures partly covers the process of frame production, an aspect that is generally overlooked in framing analyses [48].

\section{Methods}

This article is mainly based on an extensive database of published documents about climate services. It also benefits from a 4-year doctorate project that included about 50 semi-structured and informal interviews with CIS experts, frequent participation in CIS conferences and seminars, and the follow-up of CIS projects in developing countries. This experience contributed to the building of some reflections for this paper but was not directly used in the framing analysis.

Hertog and McLeod [45] emphasize the importance of drawing on ideologically divergent sources and different types of texts when conducting a discourse analysis. Therefore, a wide range of players 
and formats of publications about CIS were included. The publications come from the research realm (both academics and think tanks), international organizations, NGOs, and consultants.

Documents were selected by looking for all publications in English containing "climate services", "climate information services", and "climate adaptation services" in their titles using two distinct research tools: cible+ and Google Scholar, chosen for the rights access and complementarity they offer. This was performed at two different moments in time: the first, in December 2016, without date restrictions, and the second, in January 2019, for all publications between January 2016 and January 2019. The two searches, combined, generated a total of 1141 results. A selection and elimination process guided by format and relevance criteria was the next step: first, all duplicates, databases, and false results were deleted; second, documents too short or unsuitable for framing analysis were discarded. This included conference proceedings, info notes, most workshop reports, and activity reports. Peer-reviewed articles, book chapters, institutional, and NGO reports and working papers were systematically kept. The final database included 161 publications: 101 peer-reviewed articles, 21 reports, 16 working papers, 14 conference papers, 6 book chapters, and 3 white papers. The full list has been included in the Supplementary Materials, Table S1. Almost all the publications (159/161) came after 2002, and the majority (115/161) appeared from 2014 onwards.

Each document selected was then incorporated in the framing analysis, through a full reading process. The first step consisted of a quick screening of each document to identify its main characteristics, such as the type of contribution or origin. The second step was a careful reading of each document and the consideration of several factors for each. The points of attention were the language used, reasoning, implicit and explicit purposes, justification and legitimization of CIS, resources available, and knowledge tending to be included or excluded by the paper. Furthermore, a series of themes relevant to climate services were systematically explored, to understand how they were treated in the literature. The themes included were, among others, disciplinary specialization (both of the authors and the publication itself), the actors involved in the climate services described, models of knowledge production and dissemination, types of climate services, geographical scope (both of the authors and case studies), and financial aspects.

Five major frames around climate services were finally identified, using an inductive approach and elements of interpretation, based on every note collected in the previous step. Both the content and the institutional structures behind discourses were considered. Specifically, the agenda made apparent by each contribution was considered to identify framing processes. The relationships of the authors towards CIS were analyzed to identify their positions. Papers were then distinguished according to whether they were written by climate services producers, brokers, consultants, or external researchers. The main points of attention for defining a frame were the existence of a consistent, repeated track of arguments around climate services, the presence of group of actors pushing towards a coherent discourse, the vocabulary used, the translation of a discourse into a key hypothesis, shared assumptions, and sets of recommendations and practices for climate services. The frames identified were finally named based on the main logics or values they transmitted.

Each publication was then classified according to the dominant frame it related to. This was performed through a quick re-reading of the key elements of the document. Many of the publications were also classified as relying on more than one frame, up to three. The main frame was determined by the main objective pursued by the article (for example, was the objective to demonstrate the applicability of a climate information product or to identify user needs in a specific context?), the main arguments expressed by the author(s) (particularly in key places such as the summary, introduction, and conclusion), the presence of certain words and topics (for example, was the article mainly about producers or users of information?), and the prominence of these words. Secondary or tertiary frames were considered if a consistent and repeated argument from another frame was also present in the publication - but less strongly than the dominant one. After aggregating the publications by frames, the types and origins of all the actors involved were finally examined in each of them in order to determine their logics, values, and interest in climate services. Attention was also paid to the 
chronological and evolutionary nature of these frames as well as the way in which they challenged and responded to each other.

The methodology used presents three major limitations. First, all the documents were treated equally, but their quality and influence differ. Second, only documents specifically referring to climate services and doing so in their titles were part of the database. Third, the identification of frames has a strong interpretative element. Nevertheless, these limits do not undermine the interest of the research, which aims to be explanatory rather than exhaustive or systematic.

The documents are treated equally because the objective was to show "whom, how and to what end" [41] (p. 107) climate services are framed. This article does not propose state-of-the-art empirical knowledge about climate services but rather suggests a critical analysis of how they are discussed in the literature. Arguably, some authors or publications have more influence than others in shaping global discourses, for example, international organizations [61]. This is partially reflected by the interest in the actors behind the publications and the likelihood that the main influencers in the field were represented more than once in the database. Additionally, some CIS publications were inevitably lost because of this term being relatively new but describing a large scope of realities. Furthermore, many authors refer to climate services while not using this term specifically. Nevertheless, the number of publications incorporated in the analysis was very high. While the database represents only a portion of the publications about CIS, it is a unique depiction of the use of the term "climate services" itself in publications and reflects its current success. Therefore, this analysis can be considered as representing a discourse around this term specifically. Finally, this type of analysis, both documentand discourse-based, is extremely popular in qualitative research and has been proved to be very useful in many environmental and climate change studies $[50,54,62,63]$.

\section{Results}

\subsection{Framing Climate Services}

Five frames were identified as being dominant in CIS literature. CIS are typically described (1) as a technological innovation, (2) as a market, (3) as an interface between users and producers, (4) as a risk management tool, and (5) from an ethical angle. From the database, $38.5 \%$ of all the contributions were classified as part of the technological frame $(62 / 161) ; 36.6 \%$ as part of the interface frame $(59 / 161)$; and $13 \%$ as part of the market frame (21/161). The risk frame $(5.6 \%)$ and the ethical one $(6.2 \%)$ are more marginal. This section describes each of the frames, the actors behind them, the underlying logics, and the values and interests they come with.

\subsubsection{Climate Services as a Technological Innovation}

"The scientific opportunities arise from advances in observing and predicting atmospheric events and from rapidly developing computer and communications capabilities". [3]

"Sustained, high quality and uninterrupted climate observations are vital for the development of all countries". [64]

Climate services are perceived as the outcome of technological advances and innovation in climate research. Influenced by the rapid development of meteorology in the 20th century, this frame is carried by the hope of triggering a similar development in climatology and stimulating additional research in the field. Simply put, the technological frame is characterized by the willingness to strengthen and improve climatology as a science. "Technology" is understood here as part of the process through which scientific and technical development are progressively institutionalized to create new forms of legitimation and control [65].

The technological frame is the dominant one in terms of the number of contributions: 62 out of 161 are primarily engaged in this discourse, and 13 other documents address similar arguments. This frame mainly comes from the classic weather community, such as members of a National 
Meteorological and Hydrological Service (NMHS), but also from exact-science researchers involved in climatology, applied climatology, and modelling research [66-69]. It is also represented by weather and climate institutions such as the WMO and the United States National Oceanic and Atmospheric Administration [70,71]. As such, climate services are originally promoted and brought to the international agenda by the same institutions that have been providing for a long-time weather services [72]. Similar logics can therefore be found in those two domains, as the willingness to use data for society and the idea of services [4].

The focus of such publications is on the production of climate information, claiming the need for "more" of it, both quantitatively and qualitatively. This is justified by the idea that data, information and knowledge are the base of any climate service. Authors within the technological frame argue that (1) there are not enough data and (2) the quality of the data must be improved [22,64,73]. Therefore, on the one hand, they aim to strengthen data collection, computerization, standardization, and sharing, also diversifying the sources and means of collection of such data. Alongside classic weather and climate stations, it can include interest in GPS, drones, and satellites. On the other hand, more data are assumed to refine climate knowledge, such as for Global Circulation Models. The objective is, therefore, to increase the quality of information for climate services, the underlying idea being that reducing uncertainty will increase the use of information [74]. There is strong interest in all sorts of technologies and their capacities to create advances in science as well as building new communication platforms for decision-makers [75]. Some expected outcomes, in terms of CIS products, are an online database for users, downscaled climate scenarios and projections, customizable maps, etc., [76,77]. Publications within the technological frame often come with a call for more funding for climate research and/or strengthening the NMHS [3,70,78]. While not always specified, the calls are mostly for public rather than private funding. It is possible that the WMO and some NMHSs either fear competition in the field of climate research, which is shared with academics, and seek to (re)gain a central position or exhibit somewhat opportunistic behavior towards climate services and seek to take advantage of this new field to secure additional funding. Publications influenced by this frame are rather constant over time: the discourse has been present since the beginning [79] and originated many debates around climate services. It remains present today, while new frames have since appeared alongside it.

\subsubsection{Climate Services as a Market}

"This first challenge is to develop a comprehensive understanding of the demand and supply side of the climate services market across Europe; providing an initial snapshot of the market, the potential for growth and the support required to grow that market". [13]

"Upgrading all hydrometeorological information production and early-warning capacity in developing countries would save an average of 23,000 lives annually and would provide between US $\$ 3$ billion and US\$30 billion per year in additional economic benefits related to disaster reduction". [80]

Climate services are framed as an opportunity for the market, with an economic outlook, praising the potential payoff and aiming to escape economic losses. This frame is highly shaped by a few international organizations with some influence on academic production. From the database, 21 contributions (out of 161) were classified as being mainly influenced by this frame, while an additional 25 adopted at least some of its reasoning. It is promoted by the European Union (EU), the World Bank, and the United Nations Development Progamme. The EU is probably at the forefront of the market frame. The European Commission published in 2015 a "Roadmap for climate services" [5], which explicitly refers to the climate services market and identifies the first key challenge as enabling its growth. The European Commission launched the project EU-MACS (European Market for Climate Services) as a follow-up to the Roadmap, to explore the market structures, drivers, opportunities, and obstacles [81]. As for the authors, three origins exist: (1) publications from researchers or members of the NMHS, demonstrating the economic benefits of climate services [82,83]; (2) publications from researchers linked to or funded by the EU, following the Roadmap release [13,84]; (3) publications 
from consultants or researchers interested in the CIS market or the economic growth of a specific sector perceived as being threatened by climate change [85-88].

Three types of arguments typically belong to this frame. First, businesses and sectors need climate services. Therefore, building climate services means responding to new demand from the economic realm [86]. Second, climate services are themselves a new sector to develop. This refers to the creation of jobs and all contributions that CIS are expected to generate in economic growth $[83,89]$. Third, climate services can support mitigation, adaptation, and disaster risk reduction (DRR) strategies and therefore contribute to preventing higher costs [80]. Indeed, some analyses show that climate change leads to economic losses that rise with warming, while the "cost of action" is calculated as less important.

The market frame is driven by economic analysis and a business model to respond to the "demand" from users. It can also be performative; it is sometimes suggested that the demand should be created if it does not exist [87]. One of the manifestations of this frame is the appearance of a new type of vocabulary in the field, such as the use of the terms "client" or "consumer" to designate users of climate services $[83,86,90]$. Publications influenced by the market frame have a higher tendency to include, as users, economically attractive sectors such as oil and gas extraction, insurance, tourism, financial markets, nuclear power, pharmaceuticals, and aviation [88,91].

\subsubsection{Climate Services as an Interface Between Users and Producers}

"Despite numerous and widespread calls for more "useful" climate-science information to inform policy, most climate science is still produced in a way that is consistent with the "linear model" of research that favors pure basic research over other approaches, resulting in missed opportunities to link useful climate science with decision makers". [80]

\section{"The importance of climate services [ ... ] has gained momentum, but requires improved understanding of user needs". [23]}

Climate services are studied as an interface between the users and producers of climate information. This frame focuses on the users' side of climate services and the way in which information can be communicated to fulfil its role in decision-making. The definition of climate services is usually more precise and includes the idea of a process and relationship with users. It is only slightly less prevalent than the technological frame: 59 publications (out of 161) were classified as corresponding mainly to the interface frame, and 8 others showed some interest in this aspect of climate services. The interface frame is extremely widespread in academic production. The vast majority of such publications come from peer-reviewed articles [16,93-96] or working papers from collaborative platforms [14,97-99]. This frame is at least partially inspired by some fields of science and technology studies (STS), as they share many common themes: the science-policy interface, the role of technology and innovation, models of knowledge production, and communication.

Three themes are included in this frame, sometimes overlapping one another: (1) the existence of a gap between the users and producers of information [92,94,100]; (2) what constitutes usable and/or useful information $[16,96,101]$; (3) the use of information [102,103]. The first one is the underlying postulate for every publication in this frame: the assessment is that information is under-used and a gap between users and producers remains [33]. The diagnosis is that of a communication failure: the informational content is not adapted, poorly disseminated, or not well understood by users. Consequently, authors seek a solution at the level of information production and communication, typically having inclinations towards alternative means such as coproduction [31]. Papers investigate theories around knowledge and communication or experiment with new models with users. Strong interest is then observed in the criteria that make information useful (for example, what is relevant in terms of content) or usable (for example, which format and timing are adequate) for users. Finally, some studies assess when and how information is used, although they are less numerous. Studies in this frame involve research with users in the forms of online surveys, workshops, feedback questionnaires, focus groups, 
etc., $[23,96,104]$. Common words found in those experiences are transdisciplinary, participation, iterative process, flexibility, bottom-up, user-driven, demand-driven, and collaboration.

The interface frame represents evolution within the field of climate services. It is motivated by an assessment of a failure to reconcile users and producers, and it seeks to improve CIS efficiency. Publications from this frame come in later years, mainly after 2014, which is partially explained by the presence of new profiles of authors interested in CIS.

Interestingly, many theoretical elements used in this frame can be found in former climate information studies but not referring to climate services per se. A good example is the work of Cash et al. [105], offering a methodological framework for producing useful science and knowledge, including such for climate change issues. This framework is regularly used by scholars working in CIS but mainly in recent years rather than since the rise of climate services as a new concept.

\subsubsection{Climate Services as a Risk Management Tool}

"Discussions and subsequent reflections recognized that CS can strengthen all phases of the DRR cycle and that there are lessons to learn from experience that could enhance and demonstrate the value of CS supporting the DRR community". [106]

"Much remains to be done before climate information plays out to its full potential in reducing climate related risks". [76]

The risk frame focuses on the role that climate services can play in managing risk in societies, which is perceived to be growing with the emergence of climate change. The idea of risk (implicit or explicit) can be raised in general or be linked to climate change impacts, especially hazards, disasters, and extreme events. It is the least represented frame in terms of the number of publications: 9 (out of 161) are mainly part of the risk frame, but many others use it as secondary or tertiary frame: 63 additional publications adopt some of its arguments. Publications from the risk frame pursue some political and/or economic objective. In comparison with other frames, it seeks to create or advocate for a sense of preparedness regarding climate change and its impacts, rather than justifying or promoting climate services for themselves. The emphasis is on a broad message of the need to prepare for climate change, whereas climate services are merely a tool for decision-making. The "risk" idea is used as a general discourse and approach, rather than a research angle. This explains why this frame is more present as a second or third frame rather than the main one.

Publications from the risk frame are mainly peer-reviewed articles [106,107]. Several come or are influenced by the work of scientists from the International Research Institute for Climate and Society (IRI), a research institute from the University of Columbia, which has taken a special interest in CIS, following its original expertise in climate projections. Indeed, the IRI has developed a "climate risk management" approach [107], where climate services are a key tool. These articles take an interest in CIS for preventive and reactive adaptation: the idea is to avoid disasters and negative impacts through planification, but also to manage them after their occurrence to reduce the costs [108-110]. This frame is animated by objectives linked to disaster risk reduction alongside adaptation.

Publications from this frame take an interest in specific products that CIS can develop, such as early warning systems, impact and vulnerability assessments, research on extreme event attribution, mid-term scenarios, etc., [111,112]. CIS are often sector-based in such publications. The level of focus for users is the micro-level of policymakers-municipalities, spatial and urban planners, and citiesor very specific sectors, such as water or hydroelectricity gas distribution in a country. It is somewhat influenced by elements of the market frame, as one clear objective is to avoid economic losses. It also contains concerns similar to those contained in the interface frame, as many publications question the relationship between the users and producers of climate services, advocating for collaboration. 


\subsubsection{Climate Services from an Ethical Angle}

"Working with African American farmers [ ... ] compels us to adjust our conceptual and programmatic focus, from "equity" —ensuring parity in access to information — to "social justice"—considering how information has been or can be used to marginalize or to empower disadvantaged groups. This calls for climate services efforts to be infused with an understanding of the historical context [ ... [". [113]

"The need for a climate service ethic is significant and growing. To date, a multiplicity of competing interests and motivations across individuals and institutions has led to poor cohesion within the climate services community". [15]

The ethical frame explores what climate services involve and how they affect reality, offering some safeguards and/or recommendations for climate research and implementation. This frame is more interested in the effects of CIS alongside the ways in which they are built, diffused, and used, from a normative and ethical perspective. Ten contributions in the database (10/161) respond predominantly to such concerns, and four additional papers cover certain aspects of it. Those contributions come mainly from peer-reviewed papers $[25,36,38]$ but also include a white paper specifically referring to ethics for climate services [15] and three working papers [114].

Three angles are examined within this frame: (1) principles and rules that could guide the development of climate services [15]; (2) inequality, especially regarding access to and the use of information according to certain criteria (for example, gender, age, or wealth) $[25,113]$; (3) the direct or indirect impacts of CIS on certain critical aspects of societal systems (for example, culture, governance, and power) [36,38]. Therefore, "ethical" papers can be distinguished in two sub-groups. The first are those that aim to regulate the field and show a merely procedural concern with ethics. These contributions discuss the forms, values, and principles that govern CIS development. The second are those that deal with the politics of climate services, often from a critical perspective. Such contributions refine the understanding of producers' rationales and users' personalities and behaviors, especially those related to information-seeking and decision-making. They also investigate the potential side effects of climate services, such as increased inequality, the ability to act upon information, or the costs of climate services.

Publications from the ethical frame are still new and mainly open suggestions for future research. As for those from the interface frame, they reveal evolution within the field of climate services: new issues have emerged, and researchers are tackling them by experimenting with different approaches. It probably shows growing awareness of the need for more reflection in the study of climate services. As for the interface frame, it reveals the rising presence of new researchers in the field. Indeed, ethical papers are exclusively coming from interdisciplinary or social-science backgrounds, such as political science or anthropology.

Table 1 summarizes the main logics and values put forward by each of the five frames. The table also includes some elements of the authorship analyses.

Table 1. Framing climate services in the literature.

\begin{tabular}{cccc}
\hline Main Logics & Values & Authorship Analysis \\
\hline Technological & $\begin{array}{c}\text { More and better } \\
\text { data/information science } \\
\text { must be produced. }\end{array}$ & $\begin{array}{c}\text { Science, technology, } \\
\text { and expertise are key to } \\
\text { tackling climate change. }\end{array}$ & $\begin{array}{c}\text { "Classic" weather } \\
\text { community; scientists in } \\
\text { exact and applied sciences. }\end{array}$ \\
\hline Market & $\begin{array}{c}\text { Climate services are needed } \\
\text { and are a new market } \\
\text { to develop. }\end{array}$ & Economic growth. & $\begin{array}{c}\text { International organizations. } \\
\text { Some academics. } \\
\text { Some private }\end{array}$ \\
& \begin{tabular}{c} 
actors/consultants. \\
\hline
\end{tabular}
\end{tabular}


Table 1. Cont.

\begin{tabular}{cccc}
\hline Main Logics & Values & Authorship Analysis \\
\hline Interface & $\begin{array}{c}\text { Communication and content } \\
\text { of information must } \\
\text { be improved. }\end{array}$ & $\begin{array}{c}\text { Utilitarianism of science } \\
\text { and knowledge for } \\
\text { society. }\end{array}$ & $\begin{array}{c}\text { Academic production. } \\
\text { Researchers at large. }\end{array}$ \\
\hline Risk & $\begin{array}{c}\text { Risk management involving } \\
\text { informed decision-making. }\end{array}$ & $\begin{array}{c}\text { Mission to be prepared } \\
\text { for climate change. }\end{array}$ & $\begin{array}{c}\text { Academic production. } \\
\text { International Research } \\
\text { Institute for Climate } \\
\text { and Society. }\end{array}$ \\
\hline Ethical & $\begin{array}{c}\text { Climate services need } \\
\text { regulation, and negative } \\
\text { consequences must } \\
\text { be avoided. }\end{array}$ & $\begin{array}{c}\text { Equity and justice. } \\
\text { Inclusiveness. }\end{array}$ & $\begin{array}{c}\text { Academic production. } \\
\text { Researchers at large, } \\
\text { especially social scientists. }\end{array}$ \\
\hline
\end{tabular}

\subsection{Conceptual and Chronological Developments around Climate Serivces}

This section reviews how the dominant frames around climate services relate to one another and how they evolve over time. It offers a perspective on the discourse around the specific term CIS (or climate services) and shows how it has been shaped in different ways, especially in recent years.

\subsubsection{Chronological Evolution of Frames around Climate Services}

The historical context and emergence of climate services have been discussed in a few papers (see, for example, $[4,84]$ ). In this research, the rapid success of climate services as a concept was reflected by the increasing number of publications over time. Until 2013, the maximum number of documents published per year mentioning climate services in their titles was eight (in 2013). In 2014, this number was sixteen, and in 2018, twenty-seven. Figure 1 below shows this evolution and reflects how the term has been significantly more often used after the establishment of the GFCS (between 2009 and 2012) and in the last five years thereafter.

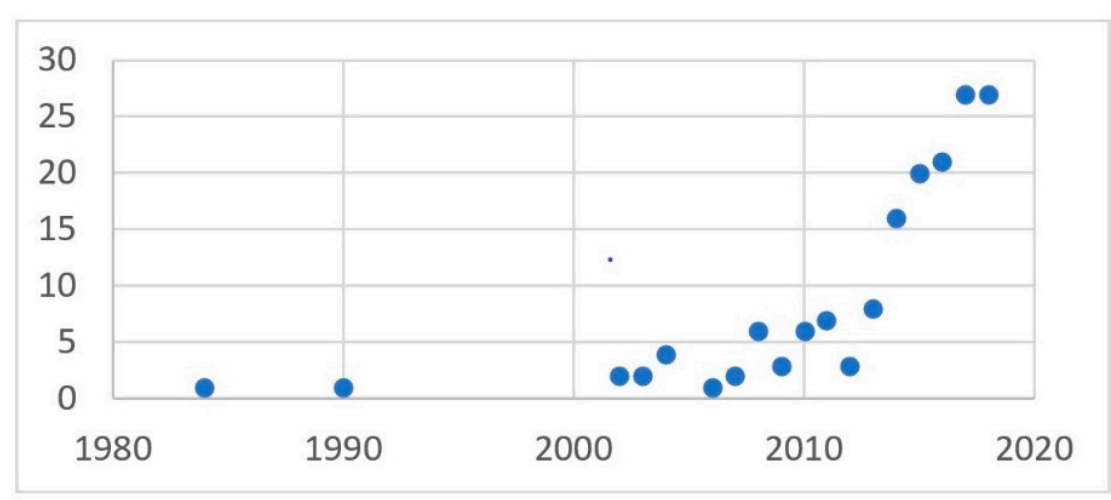

Figure 1. Number of documents per year from the database (documents from 2019 (four in total) were removed from this figure) ( $n=157$ documents).

Figure 2 depicts the evolution over time of the dominant frames around climate services within the database. It shows that the technological frame dominated the discourse on CIS in the early years. Climate services indeed come firstly from the WMO and from national meteorological centers (see Section 4.1.1), which are the main representatives of this frame. As of 2012, the interface frame becomes dominant in terms of number of publications and quickly establishes itself as the second dominant frame around CIS. Historically, this corresponds to the formal establishment of the GFCS. After 2014, while the number of publications on CIS increases considerably, three new frames emerge: the risk, ethical, and market frames; the last is the most important. 


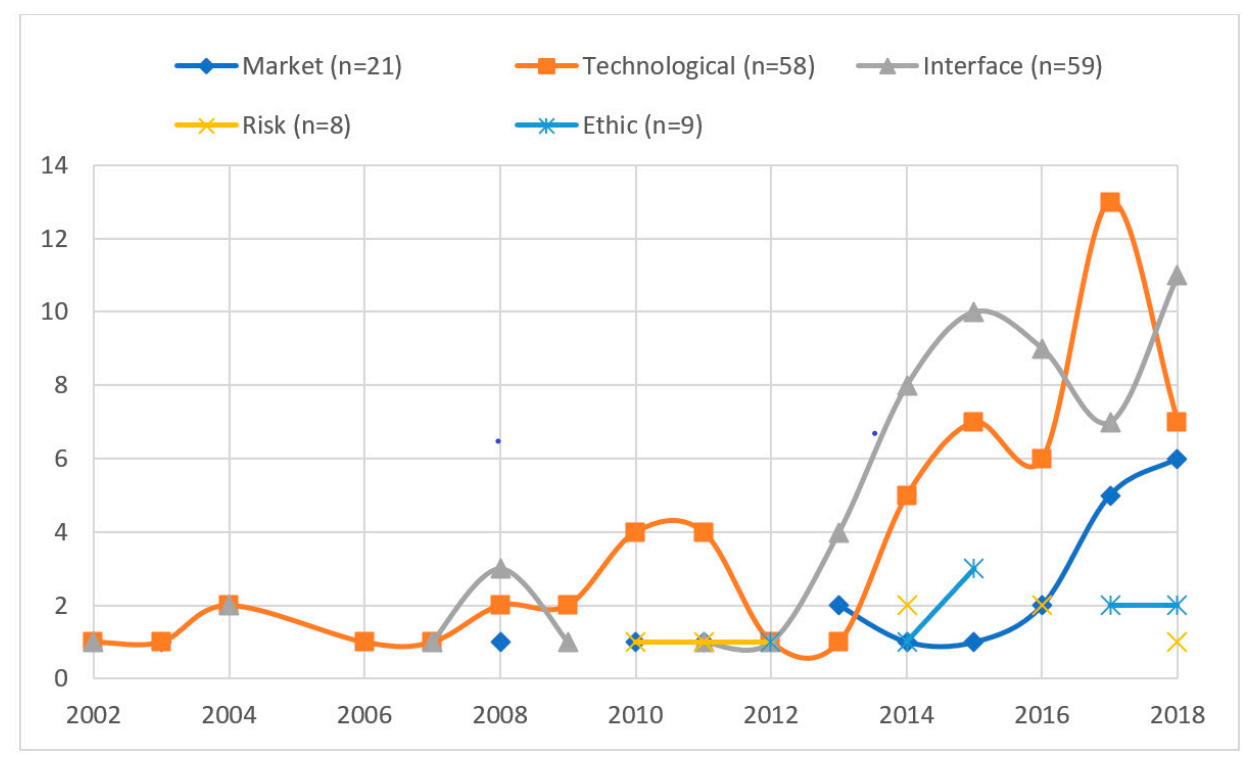

Figure 2. Chronological evolution of publications per frame (results before 2002 and after 2018 were discarded).

Half of the contributions classified as being mainly influenced by the market frame (11/21) were indeed published during the years 2017 and 2018. The growing number of publications referring explicitly to climate services after 2014 is one reason. However, the market frame is increasingly present and almost joins the technical one in 2018 (see Figure 2); other reasons explain this. First, the EU launched funding for research on CIS in 2015, leading to a series of publications influenced by the market frame. Second, a professionalization of climate services took place in the same years and led to the emergence of new types of publications on the subject, where economic motivations were preeminent [115]. Third, the market frame is influenced by international organizations whose initial publications on CIS have appeared in recent years, such as the EU [5] and the United Nations Development Programme [80]. The specific visibility of international organizations and donors inspired subsequent research on the development of a market for CIS.

\subsubsection{Interactions and Tensions between Frames}

As part of the framing analysis, interactions and possible tensions between frames were considered. In Figure 3, each frame is classified according to two axes: in the y-axis, frames are located depending on their affinity with an economic or science-based logic. In the x-axis, they are placed on the production or the use side of CIS, depending on their focus. The sizes of the circles indicate their respective strengths in terms of the numbers of documents principally representing each frame. Information about authorship is provided through color coding inside the circles, showing disciplinary backgrounds. Disciplines were identified both through the authors of the publications and the types of article considered. The disciplinary backgrounds were divided in three groups: exact sciences, interdisciplinarity, and social sciences. From the database, 71 publications (out of 157) were classified as interdisciplinary, while 65 were coded as exact and applied science (including two in natural science). Eighteen were grouped as social sciences, together with three economics papers. This confirms the general interdisciplinarity of the field, but also the relative importance of "hard" and applied sciences (mainly physics and climatology) and the relatively low share of social science and natural science studies in the field. 


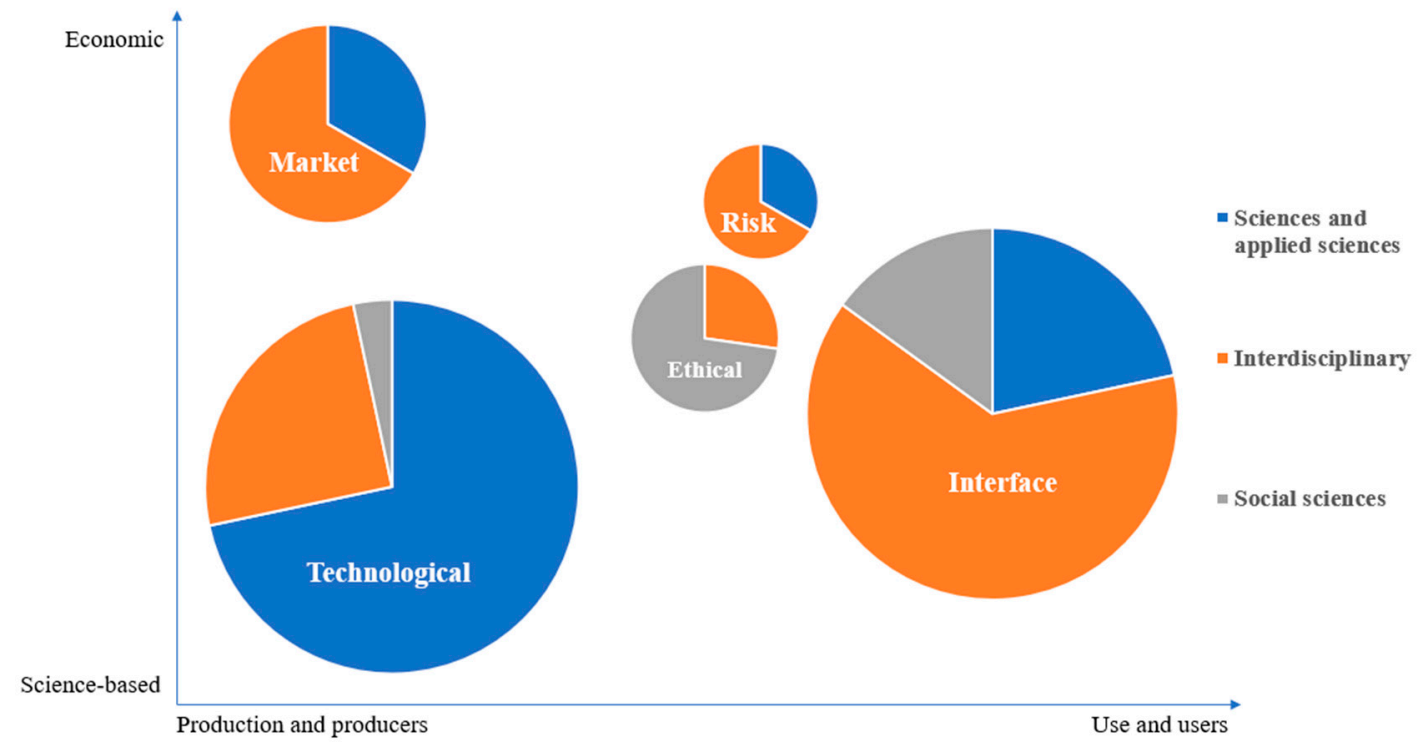

Figure 3. Disciplinary background and logics behind framing climate information services (CIS).

Figure 3 shows that exact sciences are strongly represented in the technological frame. The market, interface, and risk frames account for most interdisciplinary contributions. Finally, the ethical frame is dominated by social science contributions. Figure 3 also reveals that the production side of CIS is overrepresented in the number of publications compared to the use side, although the interest in each aspect is relatively balanced between the frames taken as a whole. There is also a strong interest in science and science-based information. This is easily understood when looking at authorship. Many publications emanate from producers or researchers of CIS. They can be motivated by the desire to highlight the usefulness of their work or to seek additional funding. As a result, climate services tend to be promoted in publications, and this contributes to the general call to produce "more" of them. Finally, the economic perspective on climate services is not the main concern in the field and remains the cornerstone of a few actors in the CIS community.

The coexistence of different frames can lead to mutual influences but also dynamics of competition or tension between communities of practice. The possible interactions between frames were examined by exploring how they correlated to one another in the database. Table 2 shows the number of publications classified in a single frame or in combination with one or two others. It therefore indicates how often two or even three frames are encountered together in a single publication. Figure 4 shows, for each frame, the number of couplings existing with other frames and therefore which frames tend to be encountered together.

Table 2. Correlations between frames in CIS literature $(n=161)$.

\begin{tabular}{ccc}
\hline Single Frame $(\boldsymbol{n}=)$ & Two Frames $(\boldsymbol{n}=)$ & Three Frames $(\boldsymbol{n}=)$ \\
\hline Technological: 33 & Interface/risk: 19 & Interface/risk/technological: 10 \\
Interface: 20 & Risk/technological: 13 & Market/risk/technological: 9 \\
Ethical: 8 & Market/technological: 12 & Interface/market/risk: 8 \\
Market: 7 & Market/risk: 7 & Ethical/interface/risk: 2 \\
Risk: 2 & Interface/market: 5 & \\
& Interface/technological: 4 & \\
& Ethical/risk: 2 & \\
& Ethical/interface: 2 & \\
\hline
\end{tabular}




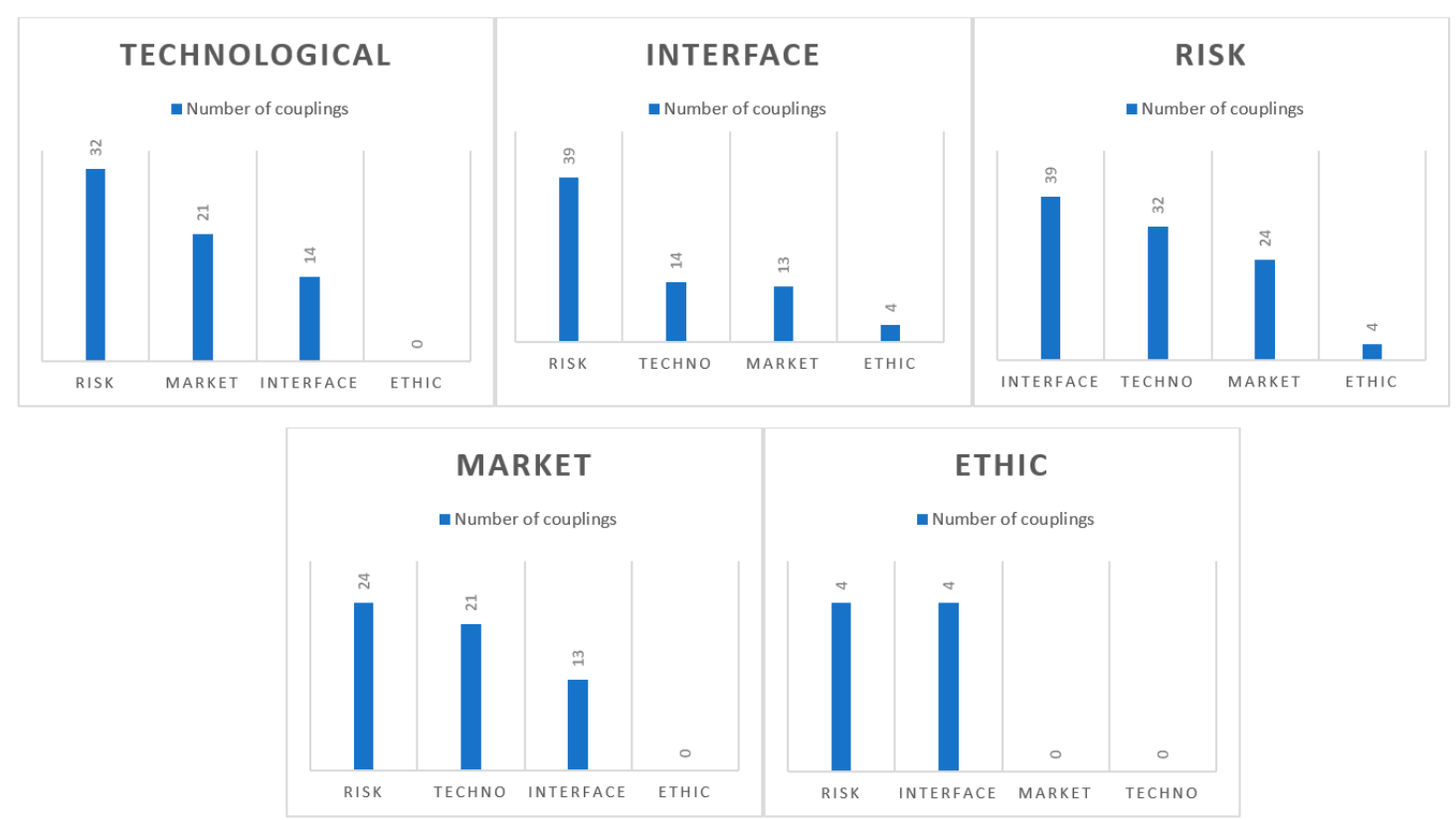

Figure 4. Two-way couplings between frames.

Table 2 and Figure 4 show the significant place of the risk frame, the most important in terms of coupled framing and the only one with the interface correlated with all the others. They also show that, all publications combined, the dominant type of publication is that inspired by the technological frame only (33/161). Next come publications containing an interface discourse only (20/161) and a combination of arguments between the interface and risk frames (19/161). Figure 4 finally reveals a relative isolation of the ethical frame. The only pairs of frames that never appear are ethical-technological and ethical-market, which is not surprising given their respective logics (see Section 4.1).

\section{Results and Discussion: Policy and Practice Regarding Climate Services}

\subsection{Cross-Cutting Issues}

Frames influence the way in which we think about CIS and the elements that are emphasized in the larger CIS agenda. For example, the importance of the technological frame explains the general call for "more" climate services, even if little is still known about their efficiency $[4,116]$. This section explores three cross-cutting issues typically encountered when dealing with CIS and shows how different frames influence their prospects. The first one is the cost of climate services. The second is the place of developing countries in CIS. The third, of a more reflexive nature, is around the evaluation of CIS and their role in adaptation to climate change.

\subsubsection{Financing Climate Services}

Producing, translating, and communicating CIS come with a cost. However, the financial or economic model that CIS should take is not a solved issue, and it remains unclear as to whether they should be built as a public or private good. Only $30 \%$ of the articles reviewed in the database refer to this problem, and of those that do, the majority do it simply by calling for more funding $(46 / 161)$, be it public (20/46), private (11/46), or a mix of both (15/46). Publications advocating for public funding sometimes come with a call for strengthening the NMHS or research in general and are mostly part of the technological or interface frame [12,117]. International Organizations (the World Bank, EU, United Nation Development Programme, and GFCS) typically call for public-private partnerships and a commercialization of climate services $[5,80,118]$. Three articles finally discuss the issue of financing climate services beyond a call for funding: one is critical of the funds usually leading to the production 
of more of the same [92], one is critical of the market model and loss of public service [36], and one reviews the influence of public funding on the development of climate services [119].

Being influenced by one frame or another leads to different economic models, with very distinct implications. For producers, who owns the data, following an open policy or not, and favoring a free or a selling model mean different things. The question of intellectual property rights in CIS, for example, has not yet been examined, but it can influence the accessibility of such services [120]. It also has implications for users, for obvious reasons. If the cost of CIS is to be covered by users, this can influence their decisions to access or not access climate information. The risk here is discarding some users with a lower ability to pay and creating inequalities. On the other hand, a model controlled by demand could participate in the development of more refined and relevant climate services products.

In the absence of regulations around the economic model and value of CIS and the increasing influence of the market frame, private or semi-private spheres in the field are likely to grow. This might lead to attracting smaller (but wealthier) target audiences. While this is not necessarily a problem everywhere, it could be more so in certain contexts than in others, such as in some developing countries.

\subsubsection{North-South Relations}

Different frames in different regions of the world will have different impacts on science and policy. The adaptation arena is marked by a frequent focus on developing countries, due to their high vulnerability to climate change. This focus is also reflected, to some extent, in the CIS community. Indeed, the GFCS considers that building CIS in developing countries is a priority and calls for voluntary funding from industrialized countries to support developing countries in doing so [72]. Developing countries are also used as examples in many papers to explain the necessity of developing climate services.

Despite the global recognition of the importance of developing countries, however, a large majority of the researchers writing about CIS come from the NMHS, research centers, and universities in the North. Developing countries are also underrepresented in terms of case studies. In the database, as displayed in Table 3, they represent about a third of all publications.

Table 3. Regional focuses of studies $(n=137)$.

\begin{tabular}{ccc}
\hline Region & Number of Studies & Relative Representation \\
\hline Africa & 31 & $21 \%$ \\
Asia & 17 & $11 \%$ \\
South America & 5 & $3 \%$ \\
North America, Central America, and the Caribbean & 29 & $19 \%$ \\
South West Pacific & 3 & $2 \%$ \\
Europe & 53 & $35 \%$ \\
Global & 13 & $9 \%$ \\
\hline
\end{tabular}

The WMO regions system [121] was used for the classification, with an additional line for climate information products with a global outreach. When a publication accounted for more than one region, each region is credited in the calculation.

As shown in Table 3, Europe is the region with the greatest number of climate services studies published as of early 2019. It is followed by Africa first and the North and Central America region second. For the latest, 22 out of the 29 studies are specifically in the United States. This is not surprising, as the United States has historically been a pioneer in the establishment of climate services [79]. With fewer studies follow Asia, the whole world, South America, and the South West Pacific, in descending order. The analysis draws on publications specifically referring to CIS and therefore does not represent the exact reality of climate services in practice. However, based on those results, one can assume that Europe, Africa, and North/Central America are the regions where more CIS case studies are implemented.

Most publications targeting developing countries are part of the interface frame and usually target primary agriculture and food security as a sector $[97,102,122])$. Others belong to the technological 
frame and expose the need for more data, and a strengthening of meteorological and climate networks and/or of the NMHS $[21,76,78])$. Very few expand beyond pilot projects or broad reflections on climate services, showing important difficulties in scaling up climate services at a national or regional scale. Almost every experience is challenged by the lack of funding to finance and sustain CIS projects, which is consistent in least developed countries (LDC)'s publications. A common solution is suggested by the market frame: publications about the willingness of farmers to pay for climate information are increasing [123-125], and this logic is reflected in some CIS projects [72]. However, in the context of extreme poverty, this is potentially worrying, as it could exclude the poorest farmers from information access. Overall, the geographical scope and local contexts of CIS projects need to be considered. A certain ambiguity in the priority given to developing countries in global discourses and the reality of investment and activities on the ground remains.

\subsubsection{Defining the Success of Climate (Adaptation) Services}

Defining what it means for a climate service to be successful is not a trivial question. By and large, belonging to one frame or another has implications for the implicit view on what is an efficient CIS, especially since some ambiguity remains over what climate services are, embrace, and exclude. For example, while some definitions specify that they differ from weather services, a few case studies include them (or short-time-scale products) as part of their climate services activity [72]. The growing number of projects labelled as climate services is partially explained by this. However, in the absence of a clear definition, the limits are blurred, and different perceptions of the same concept emerge.

The technological frame contributes to the reinforcement of climatological research. The market frame situates success in terms of economic growth. The interface frame is more interested in the process of climate services than the outcome. The risk frame is probably the most concrete in this debate: a successful climate service would be the one that increases the resilience of an entity or a sector. Finally, the ethical frame links success to characteristics such as social justice or inclusiveness. All those outcomes are of very different natures. This debate is linked to how certain ideas are outlined: what does "successful" mean, what defines information as "useful", and what is "used" information? Is the role of climate services to simply deliver climate information or to also offer concrete advice on how to interpret and use it? As adaptation is the main goal pursued by CIS, should they be communicated in a way that allows adaptation strategies?

Interestingly, adaptation to climate change is rarely considered in the evaluation of CIS. In the database, $95 \%$ of the publications relate to adaptation to climate change as an objective of climate services (122/129). Disaster risk reduction is considered by slightly more than half of the publications (74/129). Mitigation is a concern for fewer than 20\% (24/129). In the case of DRR and mitigation, it is often quoted as a potential rather than operational objective to pursue. Adaptation to climate change is therefore, to date, the main rationale behind climate services and the arena in which it is the most discussed. However, CIS are relatively little designed for adaptation. Indeed, CIS policies and projects include few thoughts about adaptation; it is generally assumed that information leads to adaptation. As a result, many articles continue to claim the importance of CIS for adaptation, while also reporting difficulties for users in accessing or effectively responding to climate information, including for adaptation strategies. Some research from the risk and the ethical frames raise interesting elements in this regard, such as when looking at users' behavior and decision-making processes. However, as those frames are more marginal in the discourse, such points are little-reflected in CIS literature. More research on the applicability of CIS, based on empirical studies, would be needed in this context.

\subsection{Perspectives on Climate Services}

Some issues finally question the perspectives of climate services, or what Bruno Soares and Buontempo call their "sustainability" [120]. 
One the one hand, CIS are now invested in by many actors: the NMHS, researchers from different disciplinary backgrounds and institutions (research centers, think tanks, and universities), NGOs, international organizations, donors, and private actors. This diversity comes with a multitude of climate services initiatives, case studies, and approaches. Therefore, it also contributes to the development of climate services in all regions of the world (although unequally), different scales of implementation, and a multitude of sectors.

On the other hand, a lack of clarity about what climate services are opens the door to confusion, misunderstanding, and even competition between communities of practice. As the framing analysis revealed, some discourses around climate services-such as the push towards economic growth on one hand, and that against inequalities of access on the other hand-seem difficult to reconcile.

A certain form of disciplinary compartmentalization and intellectual amnesia can be observed in the field. It manifests through the marginalization or ignorance of previous research about climate information or the wider field of adaptation. Indeed, climate services first emerged within a community of researchers mainly from the physical and climatological disciplines, whose conception of adaptation and vulnerabilities is a matter of physical vulnerability, focused on impacts. It took several years for contextual vulnerability approaches to inspire more research on climate services, but these had already been considered in the field of adaptation for a long time. In the same way, while the technological frame dominated the first texts referring to climate services, it was not until 2012 that the interface frame emerged and took a closer look at users. However, the disconnect between scientists and decision-makers, and the interest in participatory approaches or the coproduction of knowledge are all ideas that have long been discussed in other fields of research, such as STS. Perhaps more significantly, several studies on climate information-for instance, about the use of seasonal forecasts-have already enabled a better understanding of the factors driving such use. At the beginning of the 2000s, studies had already highlighted the need to differentiate users [126], the risks of inequalities regarding access to information [127], the need to better understand local contexts, and detach from the provision of information alone [128] or the conditions of farmers, such as differentiating their prospects for using information [129]. The importance of providing information in an appropriate format, at the right time, and responding to the needs expressed by individuals has also long been demonstrated [130]. Such findings, while important, are widely ignored in the first publications about climate services, especially from the technological and the market frames.

Why were there few connections between the research conducted on CIS specifically and on climate information, before the success of the term per se? Why is there such a consensus around the term climate services in this context?

Climate services is a smooth term that seems to appeal to common sense. However, they produce complex effects that do not necessarily or at least exclusively correspond to their goals. This apparent consensus could be a strategy through which actors erase the existence of tensions. According to Brooks [131], the use of generic terms, which obscure their technical character, actually responds to a political function: erasing the ambiguities and uncertainties that necessarily arise from divergent interests, competing agendas, and disciplinary assumptions. The political and competitive nature of CIS are almost never discussed in publications. The production of information, communication difficulties, market needs, and the risk posed by climate change are all apolitical discourses of a universal nature that ignore the individual trajectories of players, the inequalities, or even the competition resulting from the creation of an increasingly vast and multi-actor knowledge system. Such discourses are abundant in publications on climate services and are traditionally used to justify the "need" to develop them. The success of CIS, at least as a concept, can therefore also be explained by the existence of a form of opportunism from certain actors, in a context where climate change enjoys a lot of attention and, consequently, funds. The rather vague term of climate services itself, which does not benefit from a commonly agreed definition and can be described in different ways, contributes to this logic of appropriation. Arguably, this dynamic could weaken CIS perspectives in the future. Creating a dialogue between the actors influenced by different frames seems to be important for overcoming some 
of these issues. Potentially, new ways of framing climate services could emerge from such a dialogue and help to overcome common challenges such as reaching all users or effectively acting for adaptation. Such a process seems to have been happening in very recent years. While the relative degrees of importance of the market, risk, and ethical frames differ, they have emerged in more recent years and contributed to different ideas about climate services. This could be the result of more multidisciplinary within the field and the increasing impact of social scientists. Indeed, as can be seen from the database, interdisciplinary papers have increased over time. Among the 71 papers classified as interdisciplinary, 59 were published after 2014 and, therefore, the creation of the GFCS. Among them, 36 were published in 2017 and 2018 only. As for social science papers, the first dates from 2012 and each year thereafter shows a minimum of one paper per year, with a maximum of five papers in 2015.

\subsection{Recommendations for the Future of CIS}

In this final section, a few recommendations are formulated and further explained with the support of broader literature on climate information and adaptation.

First, at the research level, interdisciplinarity to increase dialogue between communities of practice and guarantee the sharing of social science seems interesting. A call for interdisciplinarity in CIS is also issued by authors such as Krauss and von Storch [132] and Brasseur and Gallardo [93], the latter specifying that it should be established in a context favoring collaboration and innovation rather than hierarchical relationships, being coordinated by a public authority. As the framing analysis revealed, social sciences (not reduced to the economic discipline alone) have played a critical role in the field of CIS. They contribute to open debates about new characteristics of CIS, such as what is useful or usable information, unequal access to information, or the appreciation of cultural factors in the transmission of information $[32,113,114,133,134]$. They are also essential for better understanding vulnerabilities, changing needs, and processes allowing the translation of information into action [135], such as the process of social learning [136]. More progress in addressing these questions is still necessary, particularly regarding the use of information and how it alleviates climate change, beyond its usability alone. On this last point, the literature on CIS still presents many gaps that could be filled by more empirical research, such as that from a multilevel and multisite perspective.

Interdisciplinary projects are not easy to establish. To guarantee interdisciplinarity, it is also important to reflect on the mechanisms put in place during a project. It is surely important to recognize the existence of leadership phenomena in any project involving more than one person, and a tendency among researchers to over-invest in the questions that particularly interest them [137]. For example, from working on biofortification projects, Brooks and Johson-Beebout [138] (p. 97) write that: "While in principle based on an interdisciplinary scheme, in practice, research tends to be compartmentalized, with particular components of research dispersed off global and heterogeneous networks of institutions and individuals, which prevents areas of contestation to develop, often when and where it is most needed". Another possible pitfall, as Verma et al. state [60], is to "add social sciences" to projects in the name of interdisciplinarity, but in a way that relegates them to the accomplishment of certain tasks and does not include them at fundamental moments such as the definition of the main agenda, research questions, or budgets. In this regard, Timmermans et al. [139], conducting a survey about interdisciplinary experiences among researchers, identify success factors acting on interdisciplinary: openness and time. The first factor refers to a warning against top-down injunction policies as well as an understanding of changes in the practices of researchers and citizens. As such, it also calls for transdisciplinarity. The second factor (time) is considered essential for fostering trust and fruitful relationships.

Second, inclusiveness in the conduct of CIS projects, for both producers and users of climate information, is necessary for the recognition of the existence of several forms of knowledge, the establishment of trust, and the guarantee of the longer-term involvement of all the stakeholders [93]. Nightingale et al. [140] propose, in this regard, going beyond traditional reflections on the interfaces between science and society and opening the door to new visions that better consider the different 
forms of existing knowledge. In other words, for these authors, it is not necessary to produce more knowledge or to improve knowledge integration, but rather, it is necessary to orient framing towards the plurality of knowledge. Indeed, simply aggregating different forms of knowledge would mean obscuring the fundamentally political nature of any knowledge formation.

Third, to reflect on the growing influence of the market frame, favoring a public service model for CIS in the poorest countries seems important. A business model inevitably comes with access and competition issues. Additionally, the push towards public-private partnerships can create difficulties in terms of power distribution and fixation of costs. While the willingness of farmers to pay has been studied as a key element for CIS development, it is necessary to consider inequalities and local contexts regarding such. In LDCs, another risk is CIS users being diverted from national meteorological services to international or regional research institutes, which would offer such services free of charge [141]. While this is not necessarily problematic for the end user, it can weaken national actors in countries where the public administrations already struggle to function. Building CIS as a public service, rather than as a private good, seems to be the best way to avoid inequalities in access due to poverty, language barriers, or a lack of social capacities. For these reasons in particular, but also because the business model has not proven the ability of the market to organize itself, some authors call for the free exchange of meteorological data as a public good [93,142]. In LDCs, this could be achieved through subsidies to the GFCS or national NMHS, such as by funding their national plans for climate services. According to Hansen et al. [142], establishing climate services as a public good requires transforming long-term data policies, as well as reorganizing NMHS funding. Overall, considerations influenced by the ethical frame seem important in the context of vulnerable and the poorest countries, to avoid worsening existing conditions.

Finally, re-thinking CIS in terms of adaptive capacities and vulnerabilities (in a vision that integrates contextual and physical vulnerability) seems fundamental. According to Webber [36], this requires engaging in the political and economic processes and contexts in which climate services are embedded. According to von Storch et al. [17], this also means understanding the socio-cultural dynamics of the settlements, rather than only the geo-systemic components of a region. Framing the problem in terms of adaptation would be helpful for several reasons. First, it would facilitate experiences through raising awareness and building capacity, interventions that go beyond the provision of scientific information and simple data collection [143]. Second, it could help in critically reflecting on vulnerability [133,135], as well as power imbalances between several levels of implementation [128,144]. In addition, this raises questions about the resources available to social actors in the field of adaptation (including the various sources and forms of knowledge), as well as their perceptions of possible adaptation responses [145]. Such resources condition adaptation success, if success is understood as the extent to which decisions made and based on climate information contribute to reducing vulnerabilities, rather than the number of forecasts provided or the quantity of information produced [135]. Fundamental to such success is involving and integrating different types of knowledge and expertise within CIS policies and projects, including those from broader communities such as those studying adaptation or development.

While those reflections are neither exhaustive nor absolute, they might represent some tracks to help reconcile climate services with their objectives regarding climate change. They also favor an exit from disciplinary silos and the overcoming of a certain amnesia observed within the CIS community, thus leading to more engagement in the processes of controversies and discussions, including between the different frames existing around climate services. Among other things, they encourage reflection on the asymmetric power structures linked to the implementation of CIS, which are particularly relevant to consider in specific cases such as North-South relations.

\section{Conclusions}

This paper presents a framing analysis of the concept of climate (information) services. It is based on an extensive literature review combining different formats and sources. Frames are important to study because they are agenda-setting and influence the definition, theorization, and processes around 
a specific topic. In the case of CIS, they can affect policy and practice in climate services projects on the ground.

Using an inductive approach, five major frames around climate services were identified in the literature. CIS are mostly presented (1) as a technological innovation, (2) as a market, (3) as an interface between users and producers, (4) as a risk management tool, and (5) from an ethical angle. Those frames are of an evolving nature and interact with one another. In particular, the technological frame, coming mainly from the classic weather community, is dominant but is being overtaken by the interface one. This means that the previous focus on information production and innovation is currently being replaced by more interest in users and user-orientated research. This indicates a growing interest in climate services in general but also the progressive inclusion of new actors invested in them, such as social scientists. Other trends are a growing interest in a commercialized model of CIS (market frame), some interest in concrete preventive risk-management strategies (risk frame) or ethical considerations regarding CIS (ethical frame).

Frames around climate services reveal different logics, agendas, and values of actors in the field. Discourses around climate services are uneven, and certain logics dominate and shape the field in specific directions. The technological and interface frames are currently the most dominant ones in the field of climate services, but the market frame has recently been gaining influence. Each of these three frames is contributing to a push towards building more and investing in climate services. They also rely on a general discourse on the need to develop climate services for society. However, while they all advocate for certain aspects around CIS to be developed (climatology as a science, communication models, and economic growth), they fall short of considering all aspects of CIS projects and practices. In particular, the analysis showed the relative isolation of the ethical frame, but it brings crucial reflections in terms of the regulation around climate services and potential negative effects. For example, little consideration is still given to the ability to act upon information, inequalities in the CIS market, and the role of information in the larger adaptation spectrum. The ethical frame, relatively marginal, ought to become mainstream in the global CIS discourse so that such aspects can reach a broader audience in the field, such as practitioners.

As the framing analysis is based on only a fraction of the papers dealing with CIS, it is not to be forgotten that the results express the situation for the use of the term "CIS" or climate services specifically. Therefore, a different sample might offer a different perspective on CIS discourses and frames. Nevertheless, these documents are also situated in the broader context of climate information literature. Doing so reveals the existence of a form of intellectual amnesia within the climate services community, which has not (yet) fully integrated some lessons learned from broader studies, including those from adaptation and climate information research. To consider all forms of knowledge, and to avoid potential negative effects on the ground, more collaborative work between different frames and communities of practice is recommended in the design and implementation of CIS. The chronological evolution of frames showed that more inclusive and multidisciplinary settings contribute to an increase in the scope and depth of CIS policies and projects, by allowing the consideration of new crucial aspects such as users' needs, capacities to act on information, inequalities, and the importance of local institutional structures to support climate services. Social science and empirical contributions contribute to more reflexive and critical approaches towards climate services, which is essential for improving their efficiency. For instance, the original focus on information production fell short of improving the so-called "user gap". Inclusiveness in climate services, and the recognition of the existence of different types of knowledge, is also a key element for favoring transformative options for adaptation. A plurality of knowledge highlights more aspects of a problem and, therefore, more solutions. Dialogue between all the stakeholders involved could help to highlight more adequate and relevant communication and practice settings, for example, through interdisciplinary and transdisciplinary approaches. Interdisciplinarity and transdisciplinarity can be encouraged through project funding and design, up to evaluation. It is time to go beyond considering why CIS should be built and to take more interest in how they can be made fit for purpose. Framing CIS in relation to their 
adaptation objectives, in terms of adaptive capacities and vulnerabilities, could be a way of moving forward from the preconceived idea that information necessarily leads to adaptation. This calls for more empirical studies on climate information use, in different contexts. This requires leaving behind the general call to support climate services, influenced by the technological frame, to commit to a more refined understanding of CIS utility for society. It can therefore help to reconcile climate services with the objectives they pursue regarding climate change, be they adaptation or disaster risk reduction. This seems fundamental, given the huge opportunity they also represent.

Supplementary Materials: The following are available online at http://www.mdpi.com/2073-4433/11/10/1047/s1. Table S1: List of climate services papers included in the analysis.

Funding: This research was funded by the Belgian Fund for Scientific Research-FNRS (F.R.S.-FNRS), through a Research Fellow (ASP-Aspirant) fellowship.

Acknowledgments: I am very thankful to Marta Bruno Soares and Edwin Zaccai for their help and comments on a previous version of this paper. I am also extremely grateful to the anonymous reviewers who helped me to greatly improve this paper.

Conflicts of Interest: The authors declare no conflict of interest.

\section{References}

1. Hewitt, C.; Mason, S.; Walland, D. The Global Framework for Climate Services. Nat. Clim. Chang. 2012, 2, 831-832. [CrossRef]

2. Tall, A. What Do We Mean by Climate Services? Available online: https://public.wmo.int/en/bulletin/whatdo-we-mean-climate-services (accessed on 4 August 2020).

3. Dutton, J.A. Opportunities and priorities in a new era for weather an climate services. Bull. Am. Meteorol. Soc. 2002, 83, 1303-1312. [CrossRef]

4. Vaughan, C.; Dessai, S. Climate services for society: Origins, institutional arrangements, and design elements for an evaluation framework: Climate services for society. Wiley Interdiscip. Rev. Clim. Chang. 2014, 5, 587-603. [CrossRef] [PubMed]

5. European Commission a European Research and Innovation Roadmap for Climate Services. Available online: https://ec.europa.eu/programmes/horizon2020/en/news/european-research-and-innovation-roadmapclimate-services (accessed on 4 August 2020).

6. Begum, R.A.; Pereira, J.J. The awareness, perception and motivational analysis of climate change and business perspectives in Malaysia. Mitig. Adapt. Strateg. Glob. Chang. 2015, 20, 361-370. [CrossRef]

7. Pasquini, L.; Cowling, R.M.; Ziervogel, G. Facing the heat: Barriers to mainstreaming climate change adaptation in local government in the Western Cape Province, South Africa. Habitat Int. 2013, 40, 225-232. [CrossRef]

8. Environment, U.N. Adaptation Gap Report 2014. Available online: http://www.unenvironment.org/resources/ adaptation-gap-report-2014 (accessed on 4 August 2020).

9. Jones, R.; Patwardhan, A.; Cohen, S.; Dessai, S.; Lammel, A.; Lempert, R.; Mirza, M.M.Q.; von Storch, H. Foundations for Decision Making. In Climate Change 2014: Impacts, Adaptation, and Vulnerability. Part A: Global and Sectoral Aspects. Working Group II contribution to the Fifth Assessment Report of the Intergovernmental Panel on Climate Change; Field, C.B., Barros, V., Dokken, D.J., Mach, K.J., Mastrandrea, M.D., Bilir, T.E., Chatterjee, M., Ebi, K.L., Estrada, Y.O., Genova, R.C., et al., Eds.; Cambridge University Press: New York, NY, USA, 2014; pp. 195-228. ISBN 978-1-107-05807-1.

10. Bokoye, A.; Bussières, L.; Cotnoir, A.; Lacroix, J.; Vescovi, L. Canadian Climate Services: Exploring an Appropriate Road Map to Fulfill a Growing Need. Bull. Am. Meteorol. Soc. 2014, 95, ES07-ES10. [CrossRef]

11. Hanger, S.; Pfenninger, S.; Dreyfus, M.; Patt, A. Knowledge and information needs of adaptation policy-makers: A European study. Reg. Environ. Chang. 2013, 13, 91-101. [CrossRef]

12. Vaughan, L.F.; Furlow, J.; Higgins, W.; Nierenberg, C.; Pulwarty, R. US Investments in International Climate Research and Applications: Reflections on contributions to interdisciplinary climate science and services, development, and adaptation. Earth Perspect. 2014, 1, 23. [CrossRef]

13. Street, R.B. Towards a leading role on climate services in Europe: A research and innovation roadmap. Clim. Serv. 2016, 1, 2-5. [CrossRef] 
14. Jones, L.; Harvey, B.; Godfrey-Wood, R. The Changing Role of NGOs in Supporting Climate Services. Available online: https://www.odi.org/publications/10560-changing-role-ngos-supporting-climate-services (accessed on 4 August 2020).

15. Adams, P.; Eitland, E.; Hewitson, B.; Vaughan, C.; Wilby, R.; Zebiak, S. Toward an Ethical Framework for Climate Services|GFCS. Available online: https://gfcs.wmo.int/EthicalFramework (accessed on 12 August 2020).

16. Goosen, H.; de Groot-Reichwein, M.A.M.; Masselink, L.; Koekoek, A.; Swart, R.; Bessembinder, J.; Witte, J.M.P.; Stuyt, L.; Blom-Zandstra, G.; Immerzeel, W. Climate Adaptation Services for the Netherlands: An operational approach to support spatial adaptation planning. Reg. Environ. Chang. 2013, 14. [CrossRef]

17. von Storch, H.; Meinke, I.; Stehr, N.; Ratter, B.; Krauss, W.; Grundmann, R.; Beckermann, M.; Weisse, R. Regional climate services illustrated with experiences from Northern Europe. Z. Umweltpolit. Umweltr. 2011, 34, 1-16.

18. Vaughan, C.; Dessai, S.; Hewitt, C. Surveying Climate Services: What Can We Learn from a Bird's-Eye View? Weather Clim. Soc. 2018, 10, 373-395. [CrossRef]

19. Lourenço, T.C.; Swart, R.; Goosen, H.; Street, R. The rise of demand-driven climate services. Nat. Clim. Chang. 2016, 6, 13-14. [CrossRef]

20. Roudier, P.; Muller, B.; d'Aquino, P.; Roncoli, C.; Soumaré, M.A.; Batté, L.; Sultan, B. The role of climate forecasts in smallholder agriculture: Lessons from participatory research in two communities in Senegal. Clim. Risk Manag. 2014, 2, 42-55. [CrossRef]

21. Lowe, R.; García-Díez, M.; Ballester, J.; Creswick, J.; Robine, J.-M.; Herrmann, F.; Rodó, X. Evaluation of an Early-Warning System for Heat Wave-Related Mortality in Europe: Implications for Sub-seasonal to Seasonal Forecasting and Climate Services. Int. J. Environ. Res. Public. Health 2016, 13, 206. [CrossRef]

22. Weisse, R.; Bisling, P.; Gaslikova, L.; Geyer, B.; Groll, N.; Hortamani, M.; Matthias, V.; Maneke, M.; Meinke, I.; Meyer, E.M.; et al. Climate services for marine applications in Europe. Earth Perspect. 2015, 2, 3. [CrossRef]

23. Vincent, K.; Dougill, A.J.; Dixon, J.L.; Stringer, L.C.; Cull, T. Identifying climate services needs for national planning: Insights from Malawi. Clim. Policy 2017, 17, 189-202. [CrossRef]

24. Rosas, G.; Gubler, S.; Oria, C.; Acuña, D.; Avalos, G.; Begert, M.; Castillo, E.; Croci-Maspoli, M.; Cubas, F.; Dapozzo, M.; et al. Towards implementing climate services in Peru-The project CLIMANDES. Clim. Serv. 2016, 4, 30-41. [CrossRef]

25. Carr, E.R.; Onzere, S.N. Really effective (for $15 \%$ of the men): Lessons in understanding and addressing user needs in climate services from Mali. Clim. Risk Manag. 2018, 22, 82-95. [CrossRef]

26. Bruno Soares, M.; Dessai, S. Barriers and enablers to the use of seasonal climate forecasts amongst organisations in Europe. Clim. Chang. 2016, 137, 89-103. [CrossRef]

27. Serra, R.; McKune, S. Climate Information Services and Behavioral Change: The Case of Senegal. 2016. Available online: https://sahelresearch.africa.ufl.edu/files/SRG_WorkingPaper_Serra_McKune_Final.pdf (accessed on 4 August 2020).

28. Tribbia, J.; Moser, S.C. More than information: What coastal managers need to plan for climate change. Environ. Sci. Policy 2008, 11, 315-328. [CrossRef]

29. Moser, S.C. Now more than ever: The need for more societally relevant research on vulnerability and adaptation to climate change. Appl. Geogr. 2010, 30, 464-474. [CrossRef]

30. Buontempo, C.; Hanlon, H.M.; Bruno Soares, M.; Christel, I.; Soubeyroux, J.-M.; Viel, C.; Calmanti, S.; Bosi, L.; Falloon, P.; Palin, E.J.; et al. What have we learnt from EUPORIAS climate service prototypes? Clim. Serv. 2018, 9, 21-32. [CrossRef]

31. Vincent, K.; Daly, M.; Scannell, C.; Leathes, B. What can climate services learn from theory and practice of co-production? Clim. Serv. 2018, 12, 48-58. [CrossRef]

32. Reinecke, S. Knowledge brokerage designs and practices in four european climate services: A role model for biodiversity policies? Environ. Sci. Policy 2015, 54, 513-521. [CrossRef]

33. Harjanne, A. Servitizing climate science-Institutional analysis of climate services discourse and its implications. Glob. Environ. Chang. 2017, 46, 1-16. [CrossRef]

34. Lombardo, E.; Meier, P. Framing Gender Equality in the European Union Political Discourse. Soc. Polit. 2009, 15. [CrossRef] 
35. Hajer, M.A.; van den Brink, M.; Metze, T.; Planning, Institutions and Transforming Spaces (AMIDST, FMG); Rethinking Politics, Transnational Society, Network Interaction and Democratic Governance (ASSR, FMG). Doing Discourse Analysis: Coalitions, Practices, Meaning. In Netherlands Geographical Studies (ISSN 0169-4839); Koninklijk Nederlands Aardrijkskundig Genootschap: Dutch, The Netherlands, 2006; ISBN 978-978-906-809-8.

36. Webber, S. Circulating climate services: Commercializing science for climate change adaptation in Pacific Islands. Geoforum 2017, 85, 82-91. [CrossRef]

37. Webber, S.; Donner, S.D. Climate service warnings: Cautions about commercializing climate science for adaptation in the developing world: Climate service warnings. Wiley Interdiscip. Rev. Clim. Chang. 2017, 8, e424. [CrossRef]

38. Haines, S. Managing expectations: Articulating expertise in climate services for agriculture in Belize. Clim. Chang. 2019, 157, 43-59. [CrossRef]

39. Schön, D.A.; Rein, M. Frame Reflection: Toward the Resolution of Intractable Policy Controversies; BasicBooks: New York, NY, USA, 1994; ISBN 978-0-465-02512-1.

40. Goffman, E. Frame Analysis: An Essay on the Organization of Experience; Northeastern University Press: Boston, MA, USA, 1986; ISBN 978-0-930350-91-8.

41. Ransan-Cooper, H.; Farbotko, C.; McNamara, K.E.; Thornton, F.; Chevalier, E. Being(s) framed: The means and ends of framing environmental migrants. Glob. Environ. Chang. 2015, 35, 106-115. [CrossRef]

42. Fünfgeld, H.; McEvoy, D. Framing Climate Change Adaptation in Policy and Practice: Working Paper 1; Victorian Centre for Climate Change Adaptation Research (VCCCAR): Melbourne, Australia, 2011; ISBN 978-0-7340-4417-4.

43. McEvoy, D.; Fünfgeld, H.; Bosomworth, K. Resilience and Climate Change Adaptation: The Importance of Framing. Plan. Pract. Res. 2013, 28, 280-293. [CrossRef]

44. D'Angelo, P. News Framing as a Multiparadigmatic Research Program: A Response to Entman. J. Commun. 2002, 52, 870-888. [CrossRef]

45. Hertog, J.K.; McLeod, D.M.; McLeod, D.M. A Multiperspectival Approach to Framing Analysis: A Field Guide. Available online: https://www.taylorfrancis.com/ (accessed on 4 August 2020).

46. Scheufele, D.A.; Tewksbury, D. Framing, Agenda Setting, and Priming: The Evolution of Three Media Effects Models: Models of Media Effects. J. Commun. 2007, 57, 9-20. [CrossRef]

47. Benford, R.D.; Snow, D.A. Framing Processes and Social Movements: An Overview and Assessment. Annu. Rev. Sociol. 2000, 26, 611-639. [CrossRef]

48. Borah, P. Conceptual Issues in Framing Theory: A Systematic Examination of a Decade's Literature. J. Commun. 2011, 61, 246-263. [CrossRef]

49. Lakoff, G. Why it Matters How We Frame the Environment. Environ. Commun. 2010, 4, 70-81. [CrossRef]

50. O'Brien, K.; Eriksen, S.; Nygaard, L.P.; Schjolden, A. Why different interpretations of vulnerability matter in climate change discourses. Clim. Policy 2007, 7, 73-88. [CrossRef]

51. Dewulf, A. Contrasting frames in policy debates on climate change adaptation: Contrasting frames on climate change adaptation. Wiley Interdiscip. Rev. Clim. Chang. 2013, 4, 321-330. [CrossRef]

52. Dupuis, J.; Knoepfel, P. The Adaptation Policy Paradox: The Implementation Deficit of Policies Framed as Climate Change Adaptation. Ecol. Soc. 2013, 18. [CrossRef]

53. Juhola, S.; Keskitalo, E.C.H.; Westerhoff, L. Understanding the framings of climate change adaptation across multiple scales of governance in Europe. Environ. Polit. 2011, 20, 445-463. [CrossRef]

54. Hulme, M. Why We Disagree about Climate Change: Understanding Controversy, Inaction and Opportunity; Cambridge University Press: Cambridge, UK, 2009; ISBN 978-0-521-89869-0.

55. Kahan, D.M.; Braman, D. Cultural Cognition and Public Policy. Policy Rev. 2006, 24, 24.

56. Wenger, E. Communities of Practice: Learning, Meaning, and Identity. In Learning in Doing: Social, Cognitive, and Computational Perspectives; Cambridge University Press: Cambridge, UK, 2008; ISBN 978-0-521-66363-2.

57. Bouwen, R. Relational Construction of Meaning in Emerging Organization Contexts. Eur. J. Work Organ. Psychol. 1998, 7, 299-319. [CrossRef]

58. Fischer, F. Reframing Public Policy: Discursive Politics and Deliberative Practices; Oxford University Press: Oxford, NY, USA, 2003; ISBN 978-0-19-924263-4. 
59. Chong, D.; Druckman, J.N. Framing Theory. Annu. Rev. Polit. Sci. 2007, 10, 103-126. [CrossRef]

60. Verma, R.; Russell, D.; German, L. Anthro-Apology? Negotiating Space for Interdisciplinary Collaboration and In-Depth Anthropology in the CGIAR Fund. Available online: https://www.cifor.org/knowledge/publication/ 3135/ (accessed on 4 August 2020).

61. Phillips, N.; Lawrence, T.B.; Hardy, C. Discourse and Institutions. Acad. Manag. Rev. 2004, $29,635-652$. [CrossRef]

62. Hajer, M.; Versteeg, W. A decade of discourse analysis of environmental politics: Achievements, challenges, perspectives. J. Environ. Policy Plan. 2005, 7, 175-184. [CrossRef]

63. Dryzek, J.S. The Politics of the Earth: Environmental Discourses; Oxford University Press: Oxford, NY, USA, 1997; ISBN 978-0-19-878160-8.

64. Manton, M.J.; Belward, A.; Harrison, D.E.; Kuhn, A.; Lefale, P.; Rösner, S.; Simmons, A.; Westermeyer, W.; Zillman, J. Observation Needs for Climate Services and Research. Procedia Environ. Sci. 2010, 1, 184-191. [CrossRef]

65. Stehr, N.; Grundmann, R. Knowledge: Critical Concepts; Taylor \& Francis: Oxfordshire, UK, 2005; ISBN 978-0-415-31740-5.

66. Heidenreich, M.; Feske, N.; Haensel, S.; Riedel, K.; Bernhofer, C.; Matschullat, J. Providing climate services for climate change adaptation-Challenges and solutions. In Proceedings of the International Scientific Conference Environmental Changes and Strategy, Skalica, Slovakia, 9-11 September 2013.

67. Graham, R.; Yun, W.; Kim, J.; Kumar, A.; Jones, D.; Bettio, L.; Gagnon, N.; Kolli, R.; Smith, D. Long-range forecasting and the Global Framework for Climate Services. Clim. Res. 2011, 47, 47-55. [CrossRef]

68. Goddard, L. From science to service. Science 2016, 353, 1366-1367. [CrossRef]

69. Termonia, P.; Van Schaeybroeck, B.; De Cruz, L.; De Troch, R.; Caluwaerts, S.; Giot, O.; Hamdi, R.; Vannitsem, S.; Duchêne, F.; Willems, P.; et al. The CORDEX.be initiative as a foundation for climate services in Belgium. Clim. Serv. 2018, 11, 49-61. [CrossRef]

70. WMO. Climate Services for Supporting Climate Change Adaptation-Supplement to the Technical Guidelines for The National Adaptation Plan Process|GFCS. Available online: https://gfcs.wmo.int/ ClimateChangeAdaptation (accessed on 4 August 2020).

71. Solomon, S.; Dole, R.M.; Feely, R.A.; Held, I.; Higgins, W.; Payne, J.L.; Shea, E.A.; Varanasi, U.; Westley, M.B. A Vision for Climate Services in NOAA. Fisheries 2009, 34, 607-609.

72. Lugen, M. Services Climatiques et Adaptation au Changement Climatique dans les Pays en Développement. Des Arènes de Construction Internationales aux Agriculteurs Bénéficiaires du Burkina Faso. Available online: http://www.secheresse.info/spip.php?article94364 (accessed on 4 August 2020).

73. Bindoff, N.L.; Stammer, D.; Le Traon, P.Y.; Trenberth, K.; Mauritzen, C.; Church, J.A.; Smith, N.; Malone, T.; Suga, T.; Tintoré, J.; et al. Capabilities of Global Ocean Programmes to Inform Climate Services. Procedia Environ. Sci. 2010, 1, 342-353. [CrossRef]

74. Otto, J.; Brown, C.; Buontempo, C.; Doblas-Reyes, F.; Jacob, D.; Juckes, M.; Keup-Thiel, E.; Kurnik, B.; Schulz, J.; Taylor, A.; et al. Uncertainty: Lessons Learned for Climate Services. Bull. Am. Meteorol. Soc. 2016, 97, ES265-ES269. [CrossRef]

75. Preuschmann, S.; Hänsler, A.; Kotova, L.; Dürk, N.; Eibner, W.; Waidhofer, C.; Haselberger, C.; Jacob, D. The IMPACT2C web-atlas-Conception, organization and aim of a web-based climate service product. Clim. Serv. 2017, 7, 115-125. [CrossRef]

76. Dinku, T.; Block, P.; Thomson, M.; Sharrof, J.; Cousin, R. Bridging critical gaps in climate services and applications in Africa. Earth Perspect. Transdiscipl. Enabled 2014, 1. [CrossRef]

77. DeGaetano, A.T.; Brown, T.J.; Hilberg, S.D.; Redmond, K.; Robbins, K.; Robinson, P.; Shulski, M.; McGuirk, M. Toward Regional Climate Services: The Role of NOAA's Regional Climate Centers. Bull. Am. Meteorol. Soc. 2010, 91, 1633-1644. [CrossRef]

78. Semazzi, F. Framework for climate services in developing countries. Clim. Res. 2011, 47, 145-150. [CrossRef]

79. Hecht, A.D. Meeting the Challenge of Climate Service in the 1980s. Bull. Am. Meteorol. Soc. 1984, 65, 365-366. [CrossRef]

80. UNDP Climate Change Adaptation. A New Vision for Weather and Climate Services in Africa. Available online: https://www.adaptation-undp.org/resources/communications-products/new-visionweather-and-climate-services-africa (accessed on 4 August 2020). 
81. EU MACS-EU MACS. Available online: http://eu-macs.eu/eu-macs/ (accessed on 4 August 2020).

82. Tall, A.; Coulibaly, J.; Diop, M. Do climate services make a difference? A review of evaluation methodologies and practices to assess the value of climate information services for farmers: Implications for Africa. Clim. Serv. 2018, 11. [CrossRef]

83. Perrels, A.; Frei, T.; Espejo, F.; Jamin, L.; Thomalla, A. Socio-economic benefits of weather and climate services in Europe. Adv. Sci. Res. 2013, 10, 65-70. [CrossRef]

84. van den Hurk, B.J.J.M.; Bouwer, L.M.; Buontempo, C.; Döscher, R.; Ercin, E.; Hananel, C.; Hunink, J.E.; Kjellström, E.; Klein, B.; Manez, M.; et al. Improving predictions and management of hydrological extremes through climate services: www.imprex.eu. Clim. Serv. 2016, 1, 6-11. [CrossRef]

85. Scott, D.; Lemieux, C.; Malone, L. Climate services to support sustainable tourism and adaptation to climate change. Clim. Res. 2011, 47, 111-122. [CrossRef]

86. Brooks, M.S. Accelerating Innovation in Climate Services: The 3 E's for Climate Service Providers. Bull. Am. Meteorol. Soc. 2013, 94, 807-819. [CrossRef]

87. Cavelier, R.; Borel, C.; Charreyron, V.; Chaussade, M.; Le Cozannet, G.; Morin, D.; Ritti, D. Conditions for a market uptake of climate services for adaptation in France. Clim. Serv. 2017, 6, 34-40. [CrossRef]

88. Georgeson, L.; Maslin, M.; Poessinouw, M. Global disparity in the supply of commercial weather and climate information services. Sci. Adv. 2017, 3, e1602632. [CrossRef] [PubMed]

89. Lechthaler, F.; Vinogradova, A. The climate challenge for agriculture and the value of climate services: Application to coffee-farming in Peru. Eur. Econ. Rev. 2017, 94, 45-70. [CrossRef]

90. Donnelly, C.; Ernst, K.; Arheimer, B. A comparison of hydrological climate services at different scales by users and scientists. Clim. Serv. 2018, 11, 24-35. [CrossRef]

91. Hoa, E.; Perrels, A.; Le, T.-T. From generating to using climate services-How the EU-MACS and MARCO projects help to unlock the market potential. Clim. Serv. 2018. [CrossRef]

92. McNie, E.C. Delivering Climate Services: Organizational Strategies and Approaches for Producing Useful Climate-Science Information. Weather Clim. Soc. 2013, 5, 14-26. [CrossRef]

93. Brasseur, G.P.; Gallardo, L. Climate services: Lessons learned and future prospects. Earths Future 2016, 4, 79-89. [CrossRef]

94. Giannini, V.; Bellucci, A.; Torresan, S. Sharing skills and needs between providers and users of climate information to create climate services: Lessons from the Northern Adriatic case study. Earth Perspect. 2016, 3,1. [CrossRef]

95. Vaughan, C.; Buja, L.; Kruczkiewicz, A.; Goddard, L. Identifying research priorities to advance climate services. Clim. Serv. 2016, 4, 65-74. [CrossRef]

96. Räsänen, A.; Jurgilevich, A.; Haanpää, S.; Heikkinen, M.; Groundstroem, F.; Juhola, S. The need for non-climate services-Empirical evidence from Finnish municipalities. Clim. Risk Manag. 2017, 16, $29-42$. [CrossRef]

97. Scaling Up Climate Services for Farmers: Mission Possible. Learning from Good Practice in Africa and South Asia. Available online: https://ccafs.cgiar.org/fr/publications/scaling-climate-services-farmers-missionpossible-learning-good-practice-africa-and (accessed on 4 August 2020).

98. Mahon, R.; Meerbeeck, C.V. Towards Baselining User Needs for Climate Services in the Caribbean. Available online: http://rcc.cimh.edu.bb/files/2016/02/Towards-Baselining-User-Needs-for-Climate-Servicesin-the-Caribbean-Prelim-CariCOF-Results.pdf (accessed on 4 August 2020).

99. Simelton, E.; Gammelgaard, J.; Le, T.T. Guide for Impact Assessment of Agro-Climate Information Services. Available online: https://ccafs.cgiar.org/publications/guide-impact-assessment-agro-climate-informationservices (accessed on 4 August 2020).

100. Buontempo, C.; Hewitt, C.D.; Doblas-Reyes, F.J.; Dessai, S. Climate service development, delivery and use in Europe at monthly to inter-annual timescales. Clim. Risk Manag. 2014, 6, 1-5. [CrossRef]

101. Lamers, M.A.J.; Knol, M.; Müller, M.; Blair, B.; Jeuring, J.H.G.; Rasmussen, T.; Sivle, A. Enhancing the Saliency of Climate Services for Marine Mobility Sectors in European Arctic Seas (SALIENSEAS): Stakeholder Advisory Group Workshop Report; Wageningen Netherlands Wageningen University Research Social Science Group: Wageningen, The Netherlands, 2018. 
102. Guido, Z.; Finan, T.; Rhiney, K.; Madajewicz, M.; Rountree, V.; Johnson, E.; McCook, G. The stresses and dynamics of smallholder coffee systems in Jamaica's Blue Mountains: A case for the potential role of climate services. Clim. Chang. 2018, 147, 253-266. [CrossRef]

103. Dayamba, D.S.; Ky-Dembele, C.; Bayala, J.; Dorward, P.; Clarkson, G.; Sanogo, D.; Diop Mamadou, L.; Traoré, I.; Diakité, A.; Nenkam, A.; et al. Assessment of the use of Participatory Integrated Climate Services for Agriculture (PICSA) approach by farmers to manage climate risk in Mali and Senegal. Clim. Serv. 2018, 12, 27-35. [CrossRef]

104. West, J.; Daly, M.; Yanda, P. Evaluating User Satisfaction with Climate Services in Tanzania 2014-2016: Summary Report to the Global Framework for Climate Services Adaptation Programme in Africa; CICERO Center for International Climate Research: Oslo, Norway, 2018.

105. Cash, D.; Clark, W.; Alcock, F.; Dickson, N.; Selin, N.; Guston, D.; Jäger, J.; Mitchell, R. Knowledge Systems for Sustainable Development. Proc. Natl. Acad. Sci. USA 2003, 100, 8086-8091. [CrossRef]

106. Street, R.B.; Buontempo, C.; Mysiak, J.; Karali, E.; Pulquério, M.; Murray, V.; Swart, R. How could climate services support disaster risk reduction in the 21st century. Int. J. Disaster Risk Reduct. 2019, 34, $28-33$. [CrossRef]

107. Hansen, J.W.; Zebiak, S.; Coffey, K. Shaping global agendas on climate risk management and climate services: An IRI perspective. Earth Perspect. 2014, 1, 13. [CrossRef]

108. Vlasova, L.V.; Rakitina, G.S. Natural Risks Management in the Gas Transmission System (GTS) of Russia and the Contribution of Climate Services Under Global Climate Change. In Management of Weather and Climate Risk in the Energy Industry; Troccoli, A., Ed.; Springer: Dordrecht, The Netherlands, 2010; pp. 315-325.

109. Ramos, M.H.; Castelletti, A.; Pulido-Velazquez, M.; Gustafsson, D. Weather and climate services for hydropower management. In Proceedings of the Hydropower and Environmental Sustainability, Grenoble, France, 16-17 March 2016; p. 5.

110. Cortekar, J.; Bender, S.; Brune, M.; Groth, M. Why climate change adaptation in cities needs customised and flexible climate services. Clim. Serv. 2016, 4, 42-51. [CrossRef]

111. Boulahya, M.S. Climate Services for Development in Africa with a Potential Focus on Energy. In Management of Weather and Climate Risk in the Energy Industry; Troccoli, A., Ed.; Springer: Dordrecht, The Netherlands, 2010; pp. 89-104.

112. Lindberg, F.; Grimmond, C.S.B.; Gabey, A.; Huang, B.; Kent, C.W.; Sun, T.; Theeuwes, N.E.; Järvi, L.; Ward, H.C.; Capel-Timms, I.; et al. Urban Multi-scale Environmental Predictor (UMEP): An integrated tool for city-based climate services. Environ. Model. Softw. 2018, 99, 70-87. [CrossRef]

113. Furman, C.; Roncoli, C.; Bartels, W.; Boudreau, M.; Crockett, H.; Gray, H.; Hoogenboom, G. Social justice in climate services: Engaging African American farmers in the American South. Clim. Risk Manag. 2014, 2, 11-25. [CrossRef]

114. Gumucio, T.; Huyer, S.; Hansen, J.; Simelton, E.; Partey, S.; Schwager, S. Inclusion of Gender Equality in Monitoring and Evaluation of Climate Services; CGIAR Research Program on Climate Change, Agriculture and Food Security (CCAFS): Wageningen, The Netherlands, 2019.

115. Keele, S. Consultants and the business of climate services: Implications of shifting from public to private science. Clim. Chang. 2019, 157, 9-26. [CrossRef]

116. Lugen, M. Le rôle des services climatiques dans l'adaptation de l'agriculture: Perspectives avec le cas du Burkina Faso. Mondes en Dev. 2019, 185, 149-164. [CrossRef]

117. Asrar, G.R.; Ryabinin, V.; Detemmerman, V. Climate science and services: Providing climate information for adaptation, sustainable development and risk management. Curr. Opin. Environ. Sustain. 2012, 4, 88-100. [CrossRef]

118. Hancock, L.; Smetanina, M. Weather and Climate Services in Europe and Central Asia: A Regional Review; World Bank: Washington, DC, USA, 2008; ISBN 978-0-8213-7585-3.

119. Shafer, M. Climate Services: Where Do We Go from Here? In Proceedings of the 14th Conference on Applied Climatology, Seattle, WA, USA, 13-16 January 2004; p. 9.

120. Bruno Soares, M.; Buontempo, C. Challenges to the sustainability of climate services in Europe. WIREs Clim. Chang. 2019, 10, e587. [CrossRef]

121. WMO Regions. Available online: http://www.earthmarineobserving.org/wmoregions/ (accessed on 5 August 2020). 
122. Coulibaly, J.; Mango, J.; Swamila, M.; Tall, A.; Kaur, H.; Hansen, J. What Climate Services Do Farmers and Pastoralists Need in Tanzania? Baseline Study for the GFCS Adaptation Program in Africa; CCAFS Working Paper No. 110; CGIAR Research Program on Climate Change, Agriculture and Food Security (CCAFS): Copenhagen, Denmark, 2015.

123. Yegbemey, R.N.; Yabi, J.A.; Heubach, K.; Bauer, S.; Nuppenau, E.-A. Willingness to be informed and to pay for agricultural extension services in times of climate change: The case of maize farming in northern Benin, West Africa. Clim. Dev. 2014, 6, 132-143. [CrossRef]

124. Zongo, B.; Diarra, A.; Barbier, B.; Zorom, M.; Yacouba, H.; Dogot, T. Farmers' Perception and Willingness to Pay for Climate Information in Burkina Faso. J. Agric. Sci. 2015, 8, 175. [CrossRef]

125. Ouedraogo, M.; Barry, S.; Zougmore, R.; Partey, S.; Leopold, S.; Baki, G. Farmers' Willingness to Pay for Climate Information Services: Evidence from Cowpea and Sesame Producers in Northern Burkina Faso. Sustainability 2018, 10, 611. [CrossRef]

126. Archer, E. Identifying Underserved End-User Groups in the Provision of Climate Information. Bull. Am. Meteorol. Soc. 2003, 84, 1525-1532. [CrossRef]

127. Roncoli, C.; Ingram, K.; Kirshen, P. The costs and risks of coping with drought: Livelihood impacts and farmers' responses in Burkina Faso. Clim. Res. 2001, 19, 119-132. [CrossRef]

128. Vogel, C.; O'Brien, K. Who Can Eat Information? Examining the Effectiveness of Seasonal Climate Forecasts and Regional Climate-Risk Management Strategies. Clim. Res. Clim. RES 2006, 33, 111-122. [CrossRef]

129. Ingram, K.T.; Roncoli, M.C.; Kirshen, P.H. Opportunities and constraints for farmers of west Africa to use seasonal precipitation forecasts with Burkina Faso as a case study. Agric. Syst. 2002, 74, 331-349. [CrossRef]

130. Tarhule, A.; Lamb, P. Climate Research and Seasonal Forecasting for West Africans: Perceptions, Dissemination, and Use? Bull. Am. Meteorol. Soc. 2003, 84. [CrossRef]

131. Brooks, S. Is international agricultural research a global public good? The case of rice biofortification. J. Peasant Stud. 2011, 38, 67-80. [CrossRef]

132. Krauss, W.; Von Storch, H. Post-Normal Practices Between Regional Climate Services and Local Knowledge. Nat. Cult. 2012, 7. [CrossRef]

133. Carr, E.; Owusu-Daaku, K. The shifting epistemologies of vulnerability in climate services for development: The case of Mali's agrometeorological advisory programme. Area 2015, 48. [CrossRef]

134. Nost, E. Climate services for whom? The political economics of contextualizing climate data in Louisiana's coastal Master Plan. Clim. Chang. 2019, 157, 27-42. [CrossRef]

135. Gerlak, A.K.; Greene, C. Interrogating vulnerability in the Global Framework for Climate Services. Clim. Chang. 2019, 157, 99-114. [CrossRef]

136. Fisher, S.; Dodman, D.; Van Epp, M.; Garside, B. The usability of climate information in sub-national planning in India, Kenya and Uganda: The role of social learning and intermediary organisations. Clim. Chang. 2018, 151, 219-245. [CrossRef]

137. Delville, P.L. Les Enquêtes Participatives en Débat: Ambition, Pratiques et Enjeux; Karthala Editions: Paris, France, 2000; ISBN 978-2-84586-116-9.

138. Brooks, S.; Johnson-Beebout, S.E.; Johnson-Beebout, S.E. Contestation as Continuity? Biofortification Research and the CGIAR. Available online: https://www.taylorfrancis.com/ (accessed on 5 August 2020).

139. Timmermans, B.; Baret, P.; Hiernaux, Q.; Lugen, M.; Nonclercq, A.; Zaccai, E. L'interdisciplinarité, ça marche! Une enquête et un colloque révèlent des facteurs de succès. Nat. Sci. Soc. 2018, 26, 67-75. [CrossRef]

140. Nightingale, A.J.; Eriksen, S.; Taylor, M.; Forsyth, T.; Pelling, M.; Newsham, A.; Boyd, E.; Brown, K.; Harvey, B.; Jones, L.; et al. Beyond Technical Fixes: Climate solutions and the great derangement. Clim. Dev. 2020, 12, 343-352. [CrossRef]

141. Harvey, B.; Jones, L.; Cochrane, L.; Singh, R. The evolving landscape of climate services in sub-Saharan Africa: What roles have NGOs played? Clim. Chang. 2019, 157, 81-98. [CrossRef]

142. Hansen, J.W.; Vaughan, C.; Kagabo, D.M.; Dinku, T.; Carr, E.R.; Körner, J.; Zougmoré, R.B. Climate Services Can Support African Farmers' Context-Specific Adaptation Needs at Scale. Front. Sustain. Food Syst. 2019, 3. [CrossRef]

143. Füssel, H.-M.; Klein, R.J.T. Climate Change Vulnerability Assessments: An Evolution of Conceptual Thinking. Clim. Chang. 2006, 75, 301-329. [CrossRef] 
144. Nagoda, S.; Nightingale, A.J. Participation and Power in Climate Change Adaptation Policies: Vulnerability in Food Security Programs in Nepal. World Dev. 2017, 100, 85-93. [CrossRef]

145. Brockhaus, M.; Djoudi, H.; Kambire, H. Multi-Level Governance and Adaptive Capacity in West Africa. Available online: https://www.cifor.org/knowledge/publication/3883/ (accessed on 5 August 2020). 